bệnh nhân bệnh gan mạn bằng đo đàn hồi gan thoáng qua đối chiếu với mô bênh học. Luận án tiến sỹ y học, Đai học Y dược Huế.

3. Gabriele Ricco, Chiara Cosma, Giorgio Bedogni et al (2020), Modeling the time-related fluctuations of AFP and PIVKA-II serum levels in patients with cirrhosis undergoing surveillance for hepatocellular carcinoma. Cancer Biomark, 2020 29(2):189-196.

4. Robert J Wong, Aijaz Ahmed, Robert G Gish (2015), Elevated alpha-fetoprotein: differential diagnosis - hepatocellular carcinoma and other disorders, Clin Liver Dis, 2015, May;19(2):309-23.

5. S. Berhane, H. Toyoda, T. Tada et al (2016). Role of the GALAD and BALAD-2 Serologic Models in Diagnosis of Hepatocellular Carcinoma and Prediction of Survival in Patients. Clin Gastroenterol Hepatol, 14 (6), 875-886.e876.

6. Chih-Wei Yen, Yuan-Hung Kuo, Jing-Houng Wang et al (2018), Did AFP-L3 save ultrasonography in community screening? Kaohsiung J Med Sci, 2018 Oct;34(10):583-587.

\title{
ĐĂC ĐIỂM LÂM SÀNG RỐI LOAN LO ÂU LAN TỎA Ở NGƯỜI BÊNH NộI TRÚ TẠI VIỆN SỨC KHỎE TÂM THẦN - BỆNH VIỆN BACH MAI NĂM 2020 - 2021
}

\author{
Vương Thị Được ${ }^{1,2}$, Trần Thanh Thủy ${ }^{1}$, Nguyễn Thị Bích ${ }^{1}$, \\ Nguyễn Thị Tuyến ${ }^{3}$, Dương Minh Tâm ${ }^{1,2}$
}

\section{TÓM TẮT}

Muc tiêu: Mô tả đăc điểm sang rối loan lo âu lan tỏa ở người bệnh điêu trị nội trú tại Viện Sức khỏe Tâm thần - Bệnh viện Bach Mai năm 2020 - 2021. Đối tượng và phương pháp: Sử dụng phương pháp mô tả cắt ngang trên 118 người bênh được chẩn đoán là rối loạn lo âu lan tỏa (F41.1) theo tiêu chuẩn chẩn đoán của ICD 10 điều trị nội trú tại Viện Sức khỏe Tâm thần - Bênh viên Bach Mai năm 2020 - 2021. Kết quả: Người bềnh RLLLALT phần lớn là nữ $(55,9 \%)$, tuổi thường gặp là từ 30 đến 49 tuổi. Tuổi trung bình của nhóm bệnh nhân nghiên cứu là 46,98 $\pm 14,27$. Mức độ lo âu thường gặp là nặng theo HAM-A (50,8\%). Phần lớn là chủ đề gia đình $(61,0 \%)$ và tai nan bệnh tật (58,5\%). Triệu chứng trong nhóm kích thích thân kinh thực vật thường gặp là hồi hộp/ tim đập mạnh/ nhanh $(93,2 \%)$. Các triệu chứng tâm thân thường găp nhất là triệu chứng chứng bồn chồn $(44,1 \%)$, triệu chứng căng dễ giật mình $(33,1 \%)$ và khó ngủ vì lo lắng $(77,1 \%)$. Các triệu chứng cơ thể thường gặp nhất là: vã mồ hôi $(60,2 \%)$, buồn nôn/khó chịu ở bụng $(42,4 \%)$, cảm giác tê cóng/kim châm $(39,8 \%)$. Kết luận: Rối loạn lo âu lan tỏa thường gặp ở nữ, tuổi từ 30 - 49, Mức độ lo âu chủ yếu là nặng, thường lo âu về chủ đề gia đình và tai nan bênh tât, triêu chứng khác thường gặp nhất là hồi hộp/ tim đập mạnh/ nhanh, khó ngư vì lo lắng, bồn chồn, dễ giật mình, cảm giác tê cóng / kim châm. điểm

Tư khóa: rối loạn lo âu lan tỏa, triệu chứng, đặc

\footnotetext{
1 Viện Sức khoẻ Tâm thần - Bệnh viện Bạch Mai,

${ }^{2}$ Trường Đại họ Y Hà Nọi

${ }^{3}$ Trường Đại học Thăng Long

Chịu trách nhiệm chính: Vương Thị Được

Email: vduochmu@gmail.com

Ngày nhận bài: 4.8.2021

Ngày phản biên khoa hoc: 1.10 .2021

Ngày duyệt bài: 11.10.2021
}

\section{SUMMARY \\ CHARACTERISTICS OF GENRALIZIED \\ ANXIETY DISORDER IN INPATIENTS IN \\ THE NATIONAL INSTITUTE OF MENTAL HEALTH AT BACH MAI HOSPITAL 2020 - 2021}

Objectives: To describe the characteristics of generalized anxiety disorder (GAD) in inpatients at the Mental Health Institute - Bach Mai Hospital in 2020 2021. Subjects and methods: Using descriptive descriptive method. Horizontal over 118 patients were diagnosed with generalized anxiety disorder (F41.1) according to ICD 10 diagnostic criteria for inpatient treatment at the Institute of Mental Health - Bach Mai Hospital in 2020 - 2021. Results: Patients with (GAD) are mostly female $(55.9 \%)$, the common age is from 30 to 49 years old. The mean age of the study group of patients was $46.98 \pm 14.27$. The most common level of anxiety was severe according to HAM-A $(50.8 \%)$. Most of the topics are family $(61.0 \%)$ and accident and illness (58.5\%). The most common symptoms in the autonomic group were palpitations or pounding heart or accelerated heart rate $(93.2 \%)$. The most common psychiatric symptoms were restlessness $(44.1 \%)$, being startled $(33.1 \%)$ and difficulty getting to sleep because of worrying (77.1\%). The most common physical symptoms were: sweating $(60.2 \%)$, Nausea or abdominal distress (42.4\%), numbness/ tingling sensation $(39.8 \%)$. Conclusion: Generalized anxiety disorder is common in women, aged 30 - 49 years, The level of anxiety is mainly severe, often worrying about family topics and illness accidents, the most common other symptoms are: palpitations or pounding heart or accelerated heart rate, difficulty getting to sleep because of worrying, restlessness, being startled, numbness/tingling sensation.

Keywords: generalized anxiety disorder, symptoms, characteristics 


\section{I. ĐĂT VẤN ĐỀ}

Rối loạn lo âu lan tỏa (RLLALT) được đăc trưng bởi tình trạng lo âu quá mức không kiểm soát được, lan tỏa nhiều chủ đề, không khu trú bất cứ tình huống đặc biệt nào, kéo dài trên 6 tháng[1]. Đây là một rối loạn phổ biến trong lâm sàng tâm thần học, thường gặp nhất trong các rối loạn lo âu được điều trị nội trú. Tại Châu Âu, tỷ lệ 12 tháng của rối loạn lo âu lan tỏa từ $0.6-$ $2.2 \%$, ảnh hưởng tới 8.9 triệu dân số, đặc biệt khu vực châu Á tỷ lệ 12 tháng từ $3.4-8.6 \%$, tỷ lệ cả đời từ $2.9-10.5 \%$ [2]'[3]. Biểu hiện lâm sàng của RLLALT rất đa dạng và phức tạp bao gồm các triệu chứng của RLLALT đa dạng và phong phú bao gồm: các triệu chứng kích thích thần kinh thực vật, các triệu chứng vùng ngực, bụng, các triệu chứng liên quan đến trạng thái tâm thần và một số triệu chứng khác [4]. Điều này không những gây khó khăn trong chẩn đoán và điều trị đối với bác sĩ mà còn gây nhiều khó khăn chẩn đoán và lập kế hoặc chăm sóc đối với điều dưỡng. Sự hỗ trợ của điều dưỡng góp một phần không nhỏ để điều trị thành công. RLLALT nếu không được điều trị sẽ gây ảnh hưởng đến sự gia tăng sử dụng dịch vụ y tế; suy giảm chất lượng hoạt động nghề nghiệp, xã hội; giảm chất lượng cuộ́c sống. Chi phí điều trị trung bình cho một trường hợp mắc rối loạn lo âu lan tỏa ở chầu Âu là khoảng $2000 \mathrm{EU} /$ năm, cao hơn so với các rối loạn lo âu khác cùng nhóm, từ 300 $1000 \mathrm{EU} /$ năm [5]. Hơn nữa, có một tỷ lệ đồng mắc cao giữa rối loạn này và việc sử dụng chất, gây tác động tiêu cực cho bản thân bệnh nhân và xã hội [2]. Với những lý do trên, chúng tôi tiến hành nghiên cứu đề tài này với mục tiêu: "Mô tả đặc điểm lâm sàng rối loạn lo âu lan tỏa ở người bệnh điều trị nội trú tại Viện Súc khỏe Tâm thần - bệnh viện Bạch Mai năm 2020 - 2021".

\section{II. ĐỐI TƯợNG VÀ PHƯƠNG PHÁP NGHIÊN CỨU}

2.1. Thiết kế nghiên cứu. Thiết kế được sử dụng là nghiên cứu cắt ngang.

\subsection{Thời gian, đối tượng và địa điểm nghiên cứu}

2.2.1. Thời gian nghiên cứu: Tháng 12 năm 2020 đến tháng 8 năm 2021.

2.2.2. Đối tượng nghiên cứu: Nghiên cứu thu nhận đối tượng tham gia là (i) Người bệnh được chẩn đoán xác địnhrối loạn lo âu lan tỏa (F41.1) theo tiêu chuẩn ICD 10; (ii) có thông tin đầy đủ về hành chính, tiền sử, bệnh sử, khám lâm sàng, các thông số cận lâm sàng; và (iii) gia đình và bản thân người bệnh đồng ý tự nguyện tham gia nghiên cứu. Nghiên cứu loại ra khỏi nghiên cứu những trẻ (i) có bệnh lý thực thể ảnh hưởng đến hoạt động chức năng não, tổn thương thực thể não kèm theo; (ii) nghiện chất hoặc lạm dụng chất; (iii) bố/mẹ/người chăm sóc hoặc không có khả năng hiểu, trả lời trong quá trình thu thập thông tin và thực hiện thang đo tâm lý, không tuân thủ quá trình nghiên cứu.

2.2.3. Địa điểm nghiên cứu: Viện sức khỏe Tâm thẩn quốc gia - Bệnh viện Bạch Mai.

2.3. Cỡ mấu và cách chọn mẫu. Nghiên cứu sử dụng cách chọn mẫu thuận tiện, lựa chọn tuần tự các bệnh nhân đáp ứng những tiều chuẩn lựa chọn ở trên trong thời gian từ tháng 12 năm 2020 đến tháng 8 năm 2021. Tổng cộng cõ mẫu thu được là 118 người bệnh.

2.4. Biến số nghiên cứu: tuổi, giới tính, mức độ lo âu, chủ đề lo âu, triệu chứng kích thích thần kinh thực vật, triệu chứng liên quan đến vùng ngực, bụng, triệu chứng toàn thân, triệu chứng liền quan đến trạng thái tâm thân, triệu chứng căng thẳng, triệu chứng không đặc hiệu khác.

\subsection{Công cụ đánh giá và thu thập số} liệu. Bệnh án nghiên cứu

Thang đánh giá lo âu Hamilton (HARS) được sử dụng để đánh giá mức độ nặng RLLALT. HARS có 14 câu hỏi cho hai nhóm triệu chứng: triệu chứng tâm thần từ câu 1 tới câu 6 và câu 14; trong khi đó các triệu chứng cơ thể từ câu 713. Thang điểm HARS được đánh giá: dưới 7 điểm là không có lo âu; từ 8-14 điểm lo âu mức độ nhẹ; từ 15-19 điểm là lo âu mức độ trung bình; trên 20 điểm là lo âu mức độ nặng.

2.6. Phân tích số liệu. Sau khi mã hóa thông tin, nghiên cứu viển trực tiếp nhập liệu bằng phần mềm SPSS 20.0 và làm sạch số liệu trước khi phân tích. Các biến định tính được thống kê mô tả với tần số và phần trăm. Các biến định lượng được thống kê mô tả với trung bình, độ lệch chuẩn, giá trị nhỏ nhất và giá trị lớn nhất.

2.7. Đạo đức nghiên cứu. Đây là nghiên cứu mô tả lâm sàng, không can thiệp vào các phương pháp điều trị của bác sĩ. Nghiên cứu được sự đồng ý của người bệnh và gia đình. Nghiên cứu được tiến hành khi có sự đồng ý của Bộ môn điều dưỡng, Trường Đại học Thăng Long, Viện Sức Khỏe Tâm Thần - Bạch Mai.

\section{KẾT QUẢ NGHIÊN CỨU}

Bảng 3.1. Phân bồ tuổi bệnh nhân nghiên cứu $(n=118)$

\begin{tabular}{|c|c|c|}
\hline Tuối & SL & \% \\
\hline$<19$ tuối & 4 & 3,4 \\
\hline
\end{tabular}




\begin{tabular}{|c|c|c|}
\hline $20-29$ tuối & 7 & 5,9 \\
\hline $30-39$ tuối & 27 & 22,9 \\
\hline $40-49$ tuối & 33 & 28,0 \\
\hline $50-59$ tuối & 17 & 14,4 \\
\hline$>60$ tuổi & 30 & 25,4 \\
\hline Tống & $\mathbf{1 1 8}$ & $\mathbf{1 0 0}$ \\
\hline$X \pm$ SD & \multicolumn{2}{|c|}{$46,98 \pm 14,27$} \\
\hline
\end{tabular}

Nhân xét: Nhóm người bệnh 30 - 39 tuổi và nhóm 40 - 49 tuổi cùng chiếm tỷ lệ cao lân lượt là 22,9\% và 28,0\%. Nhóm bệnh nhân dưới 19 tuổi chiếm tỷ lệ thấp nhất là 3,4\% (4/118 người bệnh). Tuổi trung bình của nhóm bệnh nhân nghiên cứu là 46,98 \pm 14,27tuổi.

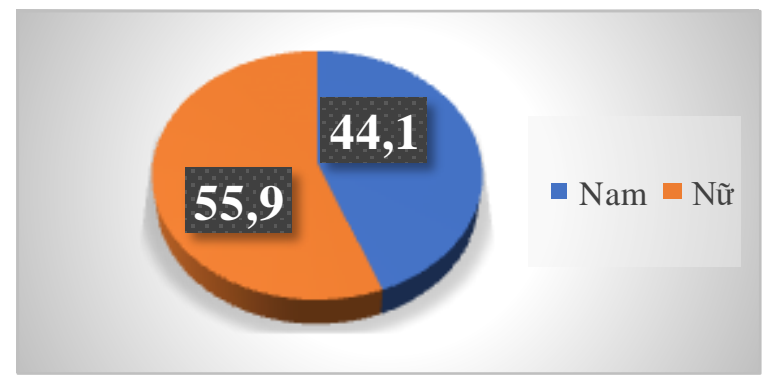

\section{Biểu đồ 3.1. Phân bố bệnh nhân theo giới tính $(n=118)$}

Nhận xét: Tỉ lệ người bệnh nữ giới cao hơn tỉ lệ người bệnh nam giới (55,9\% và 44,1\%), Tỉ lệ nữ giới / nam giới xấp xỉ khoảng 1,3/1.

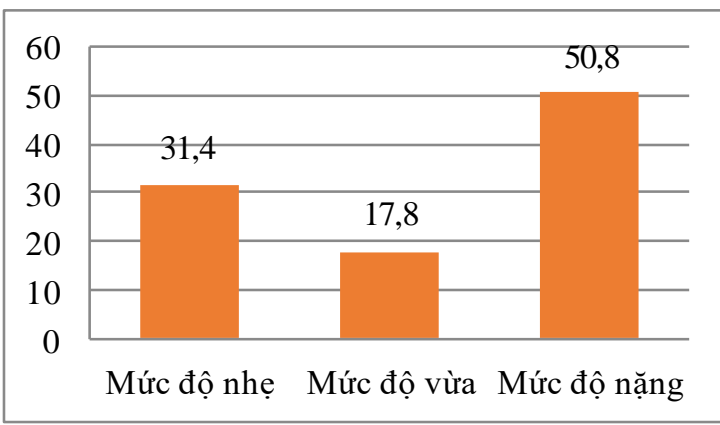

Biểu đồ 3.2. Đặc điểm mức độ lo âu theo $H A M-A(n=118)$

Nhận xét: Theo HAM-A, mức độ nặng chiếm tỉ lệ cao nhất 50,8,1\%. Tiếp đến là mức độ nhẹ với tỉ lệ 31,4\%. It gặp nhất là mức độ vừa.

Bảng 3.2. Chủ đuê lo âu thường găp ở người bệnh rôi loạn lo âu lan tỏa

\begin{tabular}{|c|c|c|}
\hline Chủ đề lo âu & SL & $\mathbf{\%}$ \\
\hline Gia đình & 72 & $\mathbf{6 1 , 0}$ \\
\hline Xã hội & 37 & 31,4 \\
\hline Công việc, học tập & 67 & 56,8 \\
\hline Tai nạn, bệnh tật & 69 & $\mathbf{5 8 , 5}$ \\
\hline Kinh tế & 49 & 41,5 \\
\hline
\end{tabular}

Nhận xét. Trong nghiên cứu, phân lớn các lo âu là chủ đề gia đình $(61,0 \%)$ và tai nạn, bệnh tật $(58,5 \%)$. Ít gặp nhất là chủ đề về xã hội $(31,4 \%)$.

\section{Bảng 3.3 Đặc điểm các triệu chứng kèm theo}

\begin{tabular}{|c|c|c|c|}
\hline Nhóm triêu chứng & Triêuu chứng & SL & $\%$ \\
\hline \multirow{4}{*}{$\begin{array}{l}\text { Nhóm kích thích thần } \\
\text { kinh thức vật }\end{array}$} & Hồi hộp/ Tim đập mạnh/ nhanh & 110 & 93,2 \\
\hline & Vã mồ hồi & 71 & 60,2 \\
\hline & Run & 52 & 44,1 \\
\hline & Khô miệng & 38 & 32,2 \\
\hline \multirow{4}{*}{$\begin{array}{l}\text { Nhóm triệu chứng ngực, } \\
\text { bụng }\end{array}$} & Khó thở & 29 & 24,6 \\
\hline & Cảm giác nghẹn & 25 & 21,2 \\
\hline & Đau/khó chịu ngực & 33 & 28,0 \\
\hline & Buồn nôn / khó chịu ở bụng & 50 & 42,4 \\
\hline \multirow{2}{*}{$\begin{array}{c}\text { Nhóm triệu chứng toàn } \\
\text { thân }\end{array}$} & Cơn nóng / lạnh & 47 & 39,8 \\
\hline & Cảm giác tê cóng / kim châm & 27 & 22,9 \\
\hline \multirow{4}{*}{$\begin{array}{l}\text { Triệu chứng liên quan } \\
\text { đến trạng thái tâm thân }\end{array}$} & Chóng măt / không vững/ngất xỉu & 32 & 27,1 \\
\hline & Tri giác sai thực tại & 33 & 28,0 \\
\hline & Sợ mất kiềm chế & 18 & 15,3 \\
\hline & Sợ bị chết & 19 & 16,1 \\
\hline \multirow{4}{*}{$\begin{array}{c}\text { Nhóm triệu chứng căng } \\
\text { thẳng }\end{array}$} & Căng cơ/đau đớn & 30 & 25,4 \\
\hline & Bồn chồn & 52 & 44,1 \\
\hline & Căng thẳng tâm thần & 24 & 20,3 \\
\hline & Cảm giác khối trong họng & 18 & 15,3 \\
\hline \multirow{4}{*}{$\begin{array}{c}\text { Nhóm triệu chứng không } \\
\text { đặc hiệu khác }\end{array}$} & Dế giật mình & 39 & 33,1 \\
\hline & Khó tập trung & 33 & 28,0 \\
\hline & Cáu kỉnh dai dắng & 10 & 8,5 \\
\hline & Khó ngủ vì lo lắng & 91 & 77,1 \\
\hline
\end{tabular}




\section{BÀN LUÂN}

4.1. Đặc điểm tuổi và giới của bệnh nhân nghiên cứu. Trong nghiên cứu, tî lệ mắc RLLALT dao đông đáng kể giữa các đố tuổi. Người ở độ tuổi dưới 19 và độ tuổi 20 - 29 có nguy cơ mắc RLLALT thấp hớn nhiều so với những người ở nhóm tuổi khác. Độ tuổi thường gặp nhất là 30 đến 39 và 40 đến 49. Tuổi trung bình của nhóm bệnh nhân nghiên cứu là 46,98 \pm 14,27 (bảng 3.1). Tương tự như vậy, nghiên cứu của Revicki (2008) trên 297 bệnh nhân tại tuyến chăm sóc sức khỏe ban đầu cũng cho kết quả tương đồng với độ tuổi trung bình là 47,6 4 13,7 [6]. Biểu đồ 3.1 cho thấy RLLALT phổ biến ở nũ giới với $55,9 \%$ hơn ở nam giới với $44,1 \%$. Tỉ lệ nữ giới gấp tỉ lệ nam giới xấp xỉ 1,3:1 lần. Trong giai đoạn trước và sau khi sinh đẻ, tức là trong giai đoạn mang thai và cho con bú, có sự thay đổi đã xảy ra trong cơ thể người phụ nữ. Một mă̆t, kích hoạt tăng tiết oxytocin, prolactin đảm bảo các quá trình sinh lý liên quan đến sinh sản. Mặt khác, phản ứng trước các sang chấn tâm lý có sự giảm đáng kể do giảm phản ứng của trục dưới đồi - tuyến yên - tuyến thượng.

4.2. Đặc điểm triệu lâm sàng chứng lo âu. Đặc điểm mức độ lo âu theo HAM - A. Biểu đồ 3.2 cho thấy, trong 118 bệnh nhân nghiên cứu, chúng tôi phát hiện thấy mức độ lo âu theo HAM-A thường gặp của bệnh nhân nghiên cứu là mức độ nặng với 60/118 người bệnh chiếm $50,8 \%$. Tiếp theo là mức độ lo âu nhẹ với $31,4 \%$. Điều này cho thấy, hầu hết bệnh nhân RLLALT đến khám và điều trị khi tình trạng bệnh ở mức độ nặng. Có thể do vấn đề kinh tế, cồng việc khiến bệnh nhân không đủ điều kiện và cố gắng chịu đựng đến lúc bệnh nặng lên. Cũng có thể do trình độ hiểu biết của bệnh nhân và nhân viên y tế về bệnh lý RLLALT khiên bệnh nhân mất nhiều thời gian trong việc khám và điều trị ở chuyên khoa khác.

Đặc điểm chủ đề lo âu. Theo tiêu chuẩn chẩn đoán ICD 10, bệnh nhân RLLALT thường lo lắng về nhiều chủ đề, ít khi khư trú vào một chủ đề nhất định. Các chủ đề lo âu của bệnh nhân là các chủ đề thường gặp trong cuộc sống hàng ngày, các chủ đề nhỏ nhặt, vụn vặt. Kết quả nghiên cứu cũng cho thấy phần lớn các chủ đề được bệnh nhân quan tâm thường là về gia đình $(61,0 \%)$ và về tai nạn, bệnh tật (bảng 3.2$)$. Sau những chủ đề về gia đình và tai nạn bệnh tật, công việc, học tập cũng là chủ đề được bệnh nhân quan tâm. Các chủ đề về xã hội ít khi được bênh nhân suy nghĩ, lo lắng $(31,4 \%)$. Tương tự với nghiên cứu của chúng tôi, một số nghiên cứu đã kiểm tra các chủ đề lo lắng ở bệnh nhân RLLALT và cho biết các chủ đề lo âu thường gặp là gia đình, tài chính, công việc, bệnh tật và chủ đề nhỏ[7]. Nghiên cứu cho kết quả bốn loai: $79 \%$ bệnh nhân báo cáo lo lắng về gia đình, $50 \%$ về tài chính, $43 \%$ về công việc, $14 \%$ vế bênh tât cá nhân và $9 \%$ về xã hội. Dugas cho biết tỉ lệ bệnh nhân RLLALT lo âu về bệnh tật / sức khoẻ / thương tích và các chủ đề khác nhiều hơn lo âu về tài chính so với nhóm chứng [7].

4.3. Đặc điểm triệu lâm sàng triệu chứng khác của RLLALT. Nhóm triệu chứng kích thích thần kinh thực vật (từ mục 1 đến mục 4). Bảng 3.3 cho thấy trong các triệu chứng thuộc nhóm triệu chứng kích thích thần kinh thực vật hầu hết là triệu chứng hồi hộp, tim đập nhanh với 93,2\%. Tiếp theo là 2 triệu chứng xuất hiện trên bệnh nhân với tỉ lệ lần lượt là triệu chứng vã mồ hồi và triệu chứng run $(60,2 \%$ và $44,1 \%)$. Ít gặp hơn là triệu chứng khô miệng.

Nhóm triệu chứng liên quan đến vùng ngực bụng. Kết quả bảng 3.3 cho thấy, phần lớn bệnh nhân có triệu chứng buồn nôn và khó chịu vùng bụng $(42,4 \%)$. Đây cũng là triệu chứng khiến bệnh nhân đi khám và điều trị ở chuyên khoa tiểu hóa. Do thần kinh giao cảm tăng hoạt động nên ở ruột, gây tăng trương lực cơ và giảm nhu động ruột làm xuất hiện các triệu chứng khó chịu ở bụng. triệu chứng thường gặp sau triệu chứng buồn nôn / khó chịu ở bụng là triệu chứng khó thở. Trong nghiên cứu, tî̉ lệ bệnh nhân có biểu hiện lâm sàng khó thở khá cao với 24,6\%. Triệu chứng xuất hiện là do ở phổi, thần kinh tự chủ tăng kích thích gây giãn tiểu phế quản phổi làm xuất hiện triệu chứng khó thở.

Nhóm triệu chứng toàn thân. Bảng 3.3 cho thấy, tỉ lệ xuất hiện triệu chứng cơn nóng / lạnh cao hơn triệu chứng cảm giác tê cóng/kim châm (39,8\% với 22,9\%). Lý do xuất hiện triệu chứng này trên lâm sàng là do rối loạn các chất dẫn truyền thần kinh và rối loạn hệ thần kinh tự chủ. Đặc biệt là rối loạn thần kinh giao cảm gầy $c 0$, giãn mạch máu bất thường làm xuất hiện triệu chứng cơn nóng/lạnh. Sự co mạch bất thường ở các động mạch nhỏ làm rối loạn sự phân bố máu vào các mô, cơ quan dẫn đến xuất hiện triệu chứng cảm giác tê cóng/kim châm. Các triệu chứng này thường khiến bệnh nhân đến khám và điêu trị tại chuyên khoa Thần kinh trước khi đến chuyên khoa Tâm thần.

Nhóm triệu chứng liên quan đến trạng thái tâm thần. Bảng 3.17 cho thấy đa số bệnh nhân có triệu chứng chóng mặt/không vững/ngất xỉu chiếm tỉ lệ $27,1 \%$. Tình trạng này có thể do rối 
loạn nhịp thở dẫn đến rối loạn nồng độ $\mathrm{CO} 2$ và O2 trong máu. Trên lâm sàng, bệnh nhân nữ thường biểu hiện lo âu căng thẳng nhiều hơn bệnh nhân nam. Hai triệu chứng sợ mất kiềm chế và sợ bị chết cũng gặp ở bệnh nhân RLLALT nhưng tỉ lê không cao. Trong nhóm này, triệu chứng chứng chóng mặt/không vững/ngất xỉu là một trong những triệu chứng khiến bệnh nhân đển thăm khám và điêu trị tại chuyên khoa Thần kinh.

Nhóm triệu chứng căng thẳng. Hầu hết bệnh nhân trong nghiên cứu có triệu chứng bồn chồn chiếm tỉ lệ 44,1\% (bảng 3.3). Tiếp đó là triệu chứng triệu chứng căng cơ / đau đớn với tỉ lệ $25,4 \%$. Sự rối loạn các chất dẫn truyền thần kinh và rối loạn thần kinh tự chủ của RLLALT dẫn đến rối loạn sự co cớ, rối loạn sự phân bố máu ở các cơ quan làm xuất hiện các triệu chứng căng cơ / đau đớn. Các triệu chứng này thường khiến bệnh nhân thăm khám tại các chuyên khoa thần kinh hoăc đa khoa.

Nhóm triệu chứng không đặc hiệu khác. Ngoài triệu chứng thường gặp là triệu chứng hồi hộp, tim đập nhanh trong nhóm 22 triệu chứng, triệu chứng khó ngủ vì lo lắng hầu hết gặp ở bệnh nhân RLLALT (77,1\%). Ngoài ra, hai triệu chứng triệu chứng dể giật mình và khó tập trung cũng thường gặp ở bệnh nhân RLLALT với tỉ lệ lần lượt là $33,1 \%$ và $28,0 \%$. Nghiên cứu nhận thấy, nhiều triệu chứng khác cũng có thể xuất hiện trong bệnh cảnh của RLLALT. Rối loạn giấc ngủ là một rối loạn thường thấy ở các bệnh nhân rối loạn tâm thần. Bệnh nhân có RLLALT có sự rối loạn về số lượng và chất giấc ngủ. Nhiều nghiên cứu cho biết rối loạn giấc ngủ ở bệnh nhân RLLALT bao gồm khó bắt đầu ngủ, giảm thời gian ngủ, khó giữ được giấc ngủ và thức giấc khó ngủ lại.

\section{KẾT LUẬN}

Bệnh nhân RLLALT phần lớn là nữ $(55,9 \%)$, tuổi thường gặp là từ 30 đến 49 tuổi. Tuổi trung bình của nhóm bệnh nhân nghiên cứu là 46,98 \pm 14,27 . Mức độ lo âu thường gặp là nặng theo HAM-A $(50,8 \%)$. Phần lớn là chủ đề gia đình $(61,0 \%)$ và tai nạn bệnh tật $(58,5 \%)$. Triệu chứng trong nhóm kích thích thần kinh thực vật thường gặp là hồi hộp/ tim đập mạnh/ nhanh $(93,2 \%)$. Các triệu chứng tâm thần thường gặp nhất là triệu chứng chứng bồn chồn $(44,1 \%)$, triệu chứng căng dễ giật mình $(33,1 \%)$ và khó ngủ vì lo lắng $(77,1 \%)$. Các triệu chứng cơ thể thường gặp nhất là: vã mồ hôi $(60,2 \%)$, buồn nôn/khó chịu ở bụng (42,4\%), cảm giác tê cóng/kim châm (39,8\%).

\section{TÀI LIÊU THAM KHẢO}

1. Đinh Đăng Hòe (2000), Bài giảng chuyên đề tâm thần hoc. Rối loạn lo âu, Bộ môn tâm thần Đai hoc Y Hà Nôi.

2. Stein D.J. (2009), Textbook of Anxiety Disorders, American Psychiatric Publishing, Inc., Washington, DC.

3. Wittchen H.U., Jacobi F., Rehm J., et al. (2011). The size and burden of mental disorders and other disorders of the brain in Europe 2010. Eur Neuropsychopharmacol, 21(9), 655-679.

4. Nguyê̂n Kim Việt (2009), Lâm sang và điêuu tri các rối loạn lo âu, Bộ môn tâm thân - Đại học Y Hà Nội.

5. Hoffman D.L., Dukes E.M., and Wittchen H.U. (2008). Human and economic burden of generalized anxiety disorder. Depress Anxiety, 25(1), 72-90.

6. Revicki D.A., Brandenburg N., Matza L., et al. (2008). Health-related quality of life and utilities in primary-care patients with generalized anxiety disorder. Qual Life Res, 17(10), 1285-1294.

7. Dugas M.J., Freeston M.H., Ladouceur R., et al. (1998). Worry themes in primary GAD secondary GAD, and other anxiety disorders. J Anxiety Disord, 12(3), 253-261.

8. Papadimitriou G.N. and Linkowski P. (2005). Sleep disturbance in anxiety disorders. Int Rev Psychiatry, 17(4), 229-236.

\section{STRESS Ở SINH VIÊN HÊ BÁC SĨ Y KHOA NĂM THỨ NHẤT TRƯỜNG ĐẠI HỌC Y HÀ NộI NĂM HỌC 2020-2021 VÀ MộT SỐ YẾU TỐ LIÊN QUAN}

\section{TÓM TẮT}

Nghiên cứu nhằm xác định tỷ lệ stress và một số yếu tố liên quan đến stress ở sinh viên năm thứ nhất

*Trường Đại học Y Hà Nội

Chịu trách nhiệm chính: Lê Thị Vũ Huyền

Email: levuhuyen@hmu.edu.vn

Ngày nhận bài: 9.8.2021

Ngày phản biên khoa hoc: 5.10 .2021

Ngày duyệt bài: 14.10 .2021

\section{Lê Thị Vũ Huyền*, Nguyễn Thị Thu Thủy*}

hê bác sĩ y khoa trường Đai hoc $Y$ Hà Nôi năm học 2020-2021. Nghiên cứu mô tả cắt ngang trền 345 sinh viên, công cu để đánh giá stress là thang DASS 21. Kết quả cho thấy $42,6 \%$ sinh viên có stress. Trong đó stress mức độ nhẹ: $17,1 \%$, stress mức độ vừa: 13,9\%, stress mức độ nặng: 8,4\%, rất nặng: 3,2\%. Các yếu tố liên quan đến stress ở sinh viền năm thứ nhất hệ bác sĩ Y khoa là: xung đột với bạn cùng phòng, kết thúc một tình bạn, rắc rối với bố mẹ, sức khỏe giảm sút, thay đổi hành vi trong việc sử dụng rượu bia, thuốc lá hoặc chất gây nghiện, gia tăng việc 